\title{
Early Permian Carbonitidae (Ostracoda): ontogeny, affinity, environment and systematics
}

\author{
JULIE B. RETRUM ${ }^{1}$ \& ROGER L. KAESLER ${ }^{1,2}$ \\ ${ }^{1}$ Department of Geology, University of Kansas, 1475 Jawhawk Blvd., Room 120, Lawrence KS 66045-7613, USA \\ ${ }^{2}$ Paleontological Institute and Natural History Museum-Biodiversity Research Center, University of Kansas, Lawrence, KS 66045-7613, USA
}

\begin{abstract}
An assemblage of four Carbonita species was deposited with charophytes, lungfishes and lysorophids in a lenticular mudstone from a Cisuralian freshwater pond deposit from the lowest Permian. Samples contained few adult Carbonita, indicating perhaps a stressed and unstable environment. Two species new to science, C. ovata n. sp. and C. triangulata n. sp., occur together with C. evelinae and C. pungens. Morphological characters of these Carbonita suggest an affinity with the Healdioidea, marine taxa that are probably ancestral to the Carbonitidae. The muscle-scar patterns of Carbonitidae, which comprise closely grouped circular bundles of secondary muscle scars, resemble closely those of Healdioidea and not those of Cypridoidea and Cytheroidea, whose muscle scars are fewer and spaced further apart. The muscle-scar pattern of $C$. pungens, described here for the first time, is a circular scar with an ascertainable pattern of secondary scars. C. pungens and species of Darwinula are morphologically similar, but study of additional specimens of $C$. pungens with better-preserved muscle scars is essential to determine their evolutionary affinity. J. Micropalaeontol. 24(2): 179-190, October 2005.
\end{abstract}

KEYWORDS: Ostracoda, Carbonita, Permian, freshwater, palaeoenvironments

\section{INTRODUCTION}

The Family Carbonitidae Swain, 1976, was distributed widely in Pangaea during the Late Palaeozoic, but research has produced mixed results regarding its evolutionary relationships, ontogeny and palaeoenvironmental significance. Differences of opinion regarding these aspects of the Carbonitidae have been attributed to poorly preserved specimens (Bless \& Pollard, 1973) and to inaccurate illustrations and imprecise descriptions (Anderson, 1970; Bless \& Pollard, 1973). The purpose of this paper is to re-evaluate these aspects of Carbonitidae by studying a Permian fauna from Wolfcampian rocks of the Midcontinent of North America. The species that comprise the fauna lived in a freshwater pond. The ontogeny of four species is traced, two new species of the genus Carbonita Strand, 1928 are described and evidence for the affinity of Carbonita to the healdiid ostracodes is provided, suggesting that their invasion of the continental freshwater environment was a separate event from that of the Cypridoidea Baird, 1845, Cytheroidea Baird, 1850 and, very likely, the Darwinuloidea Brady \& Norman, 1889.

The Speiser Shale (Cisuralian, Asselian) near Eskridge, Kansas, contains a lens of green, carbonate-rich mudstone and claystone with abundant Carbonita (Schultze, 1985; Hembree et al., 2004). C. evelinae (Jones, 1870), C. pungens (Jones \& Kirkby, 1867 ) and two new species, C. ovata n. sp. and C. triangulata n. sp., occur in the lens of mudstone (Pl. 1).

Some previous researchers regarded Carbonitidae as having close evolutionary relationships with modern freshwater Cypridoidea (Scott \& Summerson, 1943; Swain, 1976). In contrast, Sohn (1985) suggested that Carbonita evolved from the Late Palaeozoic marine Healdioidea Harlton, 1933. More recently, Whatley et al. (1993) classified the family in the Order Podocopida Müller, 1894, suborder and superfamily uncertain.

\section{THE LOCALITY}

The Speiser Shale is the youngest stratigraphic unit in the Council Grove Group (Cisuralian, Asselian) (Fig. 1). It was deposited near the shoreline of a shallow epeiric sea. Early in the Permian, the North American Midcontinent was located in the tropics (Frazier \& Schwimmer, 1987) and glaciers on Gondwana were retreating and advancing, causing glacioeustatic sea-level changes (Dickinson et al., 1994; Olszewski \& Patzkowsky, 2003). The Speiser Shale was deposited during a relative lowstand of sea-level (C. R. Cunningham, pers. comm., 1989), during which the North American Midcontinent did not receive monsoonal rains. As a result, conditions were more arid than during eustatic highs (Rankey, 1997; Olszewski \& Patzkowsky, 2003).

The Speiser Shale overlies the Funston Limestone and is overlain by the Wreford Limestone. The Speiser Shale crops out across Kansas from Marshall and Nemaha Counties in the north to Cowley County in the south. It ranges in thickness from $10 \mathrm{~m}$ in the north to $39 \mathrm{~m}$ in the south (Hattin, 1957), but is much thinner in the area studied.

Approximately $3 \mathrm{~km}$ northwest of Eskridge, Kansas, on Kansas Highway 4 is a road cut about $100 \mathrm{~m}$ long that exposes $8 \mathrm{~m}$ of section, including the top of the Funston Limestone, the Speiser Shale and the base of the Wreford Limestone (Fig. 2). The Speiser Shale is $4.2 \mathrm{~m}$ thick at this locality and contains ten distinct lithofacies, including a green, carbonate-rich mudstone and claystone lens with abundant vertebrate and invertebrate fossils. (For further descriptions of the lithofacies see Hembree et al., 2004.) This outcrop was chosen for study because of its well-studied flora and vertebrate and invertebrate fauna, including abundant Ostracoda (Schultze, 1985; Hembree et al., 2004; Watabe \& Kaesler, 2004).

\section{THE SAMPLES}

Samples were collected from intervals $5 \mathrm{~cm}$ thick from the western and eastern parts of the mudstone lens; a total of eight samples, each about $2.5 \mathrm{~kg}$ in weight, were collected. The samples were dried, crushed coarsely and treated with Amosol (Stoddard's solvent) to disaggregate the mudstone. The residues were wet sieved through 20 -mesh $(833 \mu \mathrm{m}), 100$-mesh $(149 \mu \mathrm{m})$ 


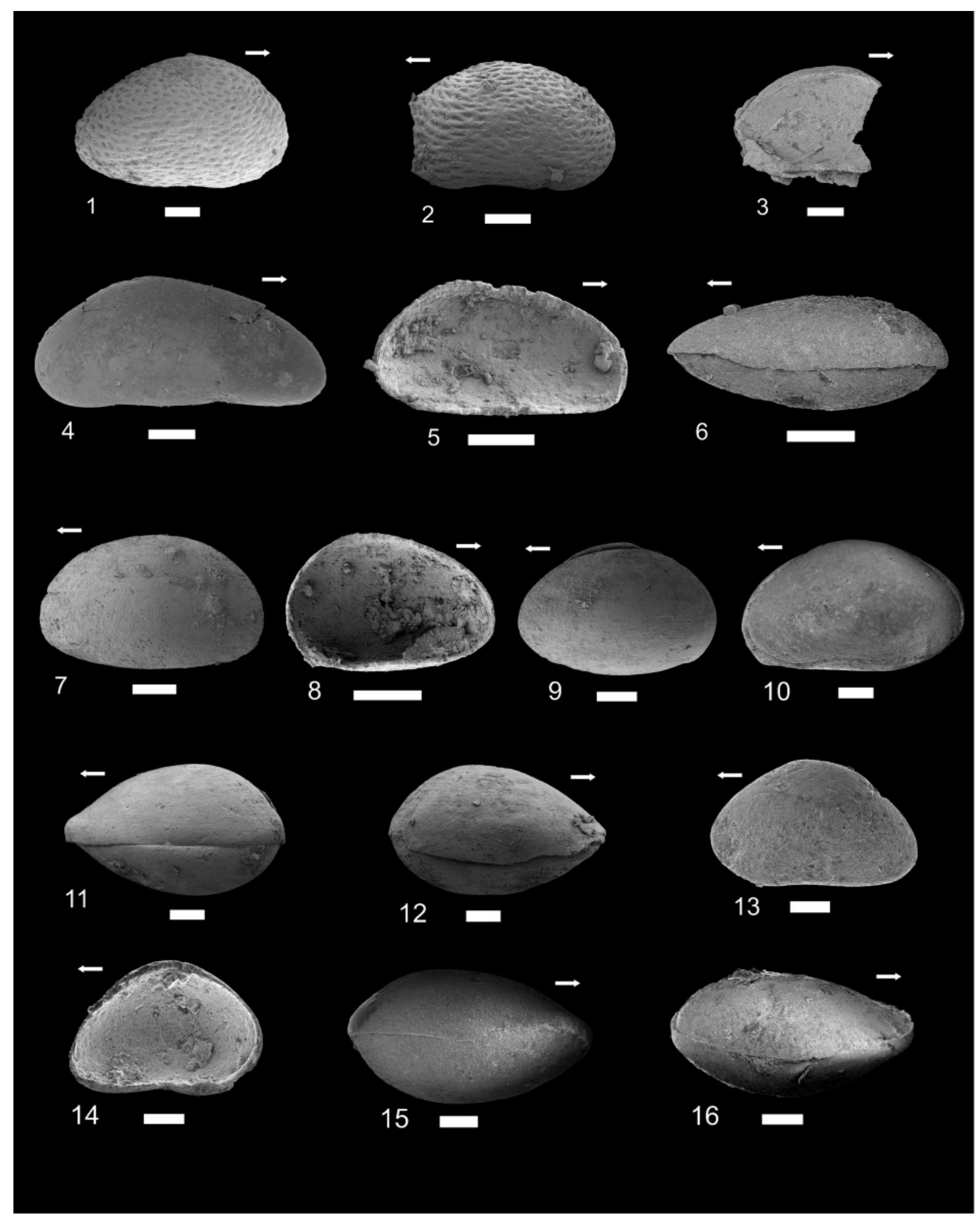

Explanation of Plate 1.

SEM photomicrographs of Carbonita species from the Speiser Shale, Eskridge, Kansas, depicting morphological features of instars and adults. All scale bars are $100 \mu \mathrm{m}$. figs 1-3. Carbonita evelinae (Jones, 1870): 1, right valve, exterior, A-1, KUMIP 1,136,686; 2, left valve, exterior, A-2, KUMIP 1,136,687; 3, left valve, interior, KUMIP 1,136,688. figs 4-6. C. pungens (Jones \& Kirkby, 1867): 4, right valve, exterior, Adult, KUMIP 1,136,690; 5, left valve, interior, A-1, KUMIP 1,136,691; 6, ventral view, steinkern, KUMIP 1,136,692. figs 7-12. C. ovata n. sp.: 7, left valve, exterior, A-1, holotype KUMIP 1,136,671; 8, left valve, interior, A-3, paratype KUMIP 1,136,672; 9, left valve, steinkern, note the overlap of the right valve along the dorsal margin, paratype KUMIP 1,136,673; 10, right valve, steinkern, paratype KUMIP 1,136,674; 11, dorsal view, steinkern, paratype KUMIP 1,136,675; 12, ventral view, steinkern, paratype KUMIP 1,136,676. figs 13-16. C. triangulata n. sp.: 13, left valve, exterior, A-1, paratype KUMIP $1,136,681 ; \mathbf{1 4}$, right valve, interior, A-1, note the circular muscle-scar, holotype KUMIP 1,136,680; 15, ventral view, steinkern, paratype KUMIP 1,136,682; 16, dorsal view, steinkern, paratype KUMIP 1,136,683. 


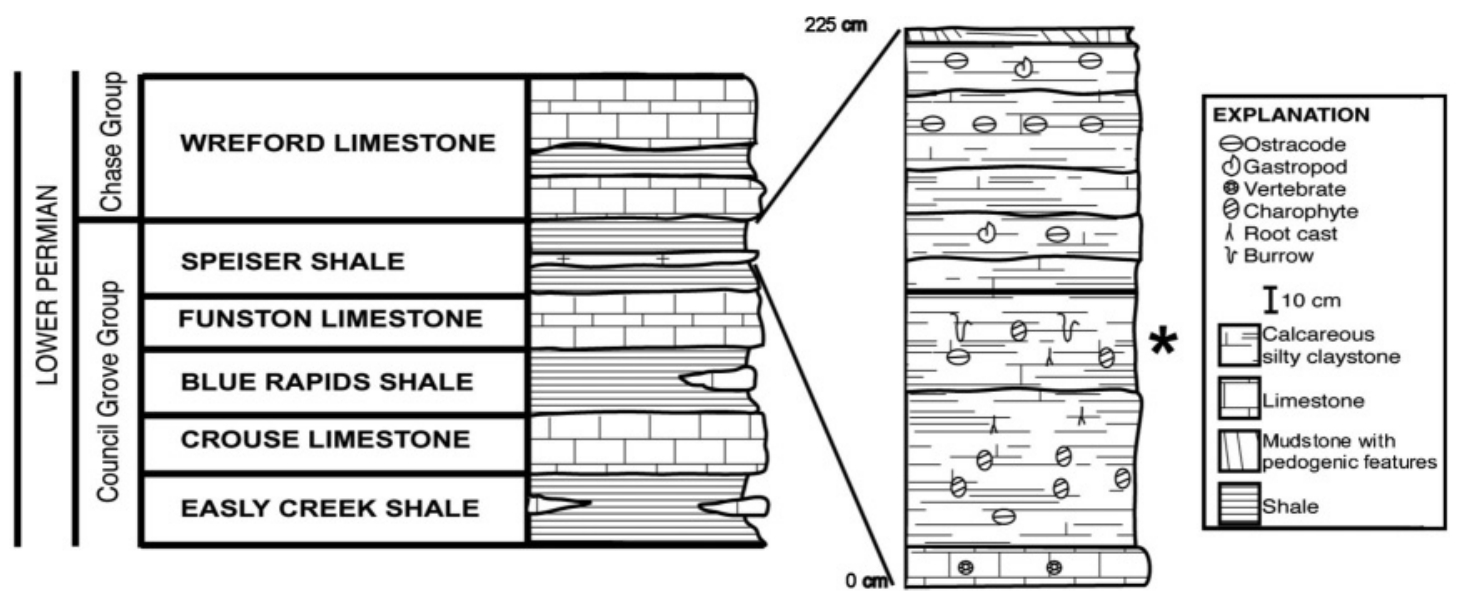

Fig. 1. Stratigraphy of the Speiser Shale at the Eskridge outcrop showing associated formations (Zeller, 1968). Carbonita specimens were collected from a green mudstone layer indicated by the asterisk (modified from Watabe \& Kaesler, 2004).

and 200-mesh $(74 \mu \mathrm{m})$ sieves to remove mud and clay particles. Carbonita is rare in all samples except for one in which $C$. ovata n. sp. and $C$. triangulata n. sp. were abundant. Lengths and heights of all specimens of Carbonita were measured and the ontological growth series of each species were plotted. Adult valves of $C$. ovata n. sp. and $C$. triangulata n. sp. were also measured for width to determine if sexual dimorphism occurs in these species. Scanning electron microscopy (SEM) photomicrographs show shell ornamentation, a few poorly preserved muscle scars, hinges and other internal features.

\section{HISTORY OF CARBONITIDAE}

Jones (1870) was the first to describe and classify Carbonitidae ostracodes. He distinguished the Family Carbonitidae from other known ostracodes by its circular muscle-scar pattern with secondary muscle-scar bundles and vascular impressions on reticulated valves (Anderson, 1970).
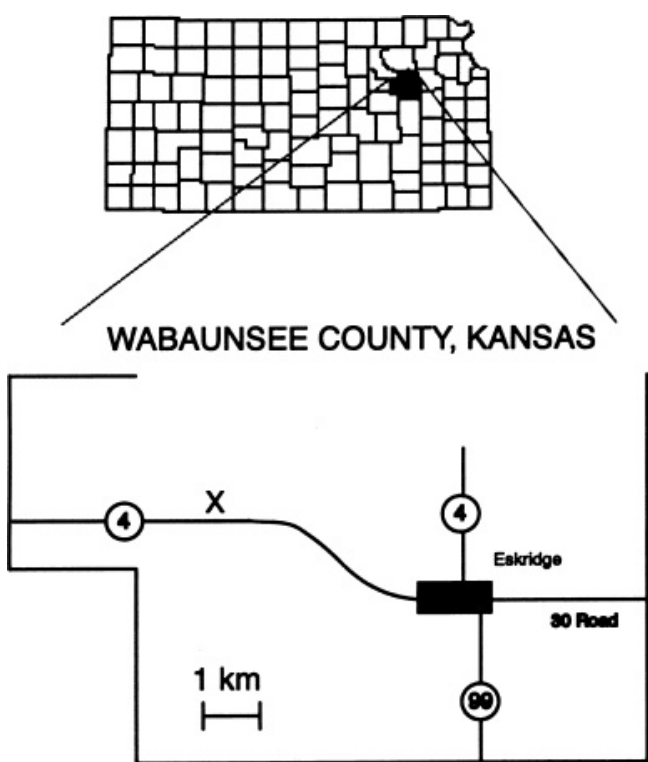

Fig. 2. Location of the outcrop, $\mathrm{X}$ (lat. $39^{\circ} 6.3^{\prime} \mathrm{N}$, long $96^{\circ} 8.8^{\prime} \mathrm{W}$ ) approximately $3 \mathrm{~km}$ northwest of Eskridge, Kansas, in Wabaunsee County.
The first known Carbonitidae evolved during the Mississippian, while the youngest are known from the Cisuralian or Guadalupian in the Permian (Cooper, 1942; Kellett, 1943). During this time, Carbonitidae had a wide distribution throughout Europe and North America in continental freshwater deposits (Scott \& Summerson, 1943) and other presumably lowsalinity deposits with marine to estuarine affinities (Jones \& Kirkby, 1879; Knight, 1928; Anderson, 1970; Tibert \& Scott, 1999). Carbonitids are most common in deposits of freshwater swamps, slow streams and lagoons, all of which received freshwater (Scott \& Summerson, 1943). The presence of Carbonitidae in marine and estuarine deposits indicates that some species may have tolerated oligohaline conditions or were transported from nearby freshwater habitats (Pollard, 1966).

The classification of genera now grouped into the Family Carbonitidae was debated widely during the twentieth century. Knight (1928) placed Carbonita into the Superfamily Cytheroidea because of the presence of a single species in marine deposits. Scott \& Summerson (1943) compared Carbonita fabulina (Jones \& Kirkby, 1867) to the modern freshwater species Cypridopsis vidua (Müller, 1776) and placed carbonitids into the Family Cyprididae Baird, 1845, having found no significant differences in the carapaces that would justify their being classified elsewhere. Swain (1976) placed the carbonitids into a separate family, Carbonitidae, which he erected based on their elongate-elliptical outline that is uncommon in species of Cypridopsis Brady, 1867. More recently, Sohn (1985) determined that the muscle scars of Carbonitidae resemble closely those of the marine Healdioidea and not of the Cypridoidea. He erected the Superfamily Carbonitoidea and, again, the Family Carbonitidae. Other researchers have found no conclusive evidence for classification of the carbonitids and placed them into an uncertain suborder and superfamily of the Order Podocopida (Whatley et al., 1993).

\section{ONTOGENY AND SEXUAL DIMORPHISM}

Four species of Carbonita occur in the Eskridge samples, including two previously undescribed species: $C$. evelinae, $C$. pungens, $C$. ovata $\mathrm{n}$. sp. and $C$. triangulata $\mathrm{n}$. sp. All specimens were preserved either as finely recrystallized valves or as steinkerns. 


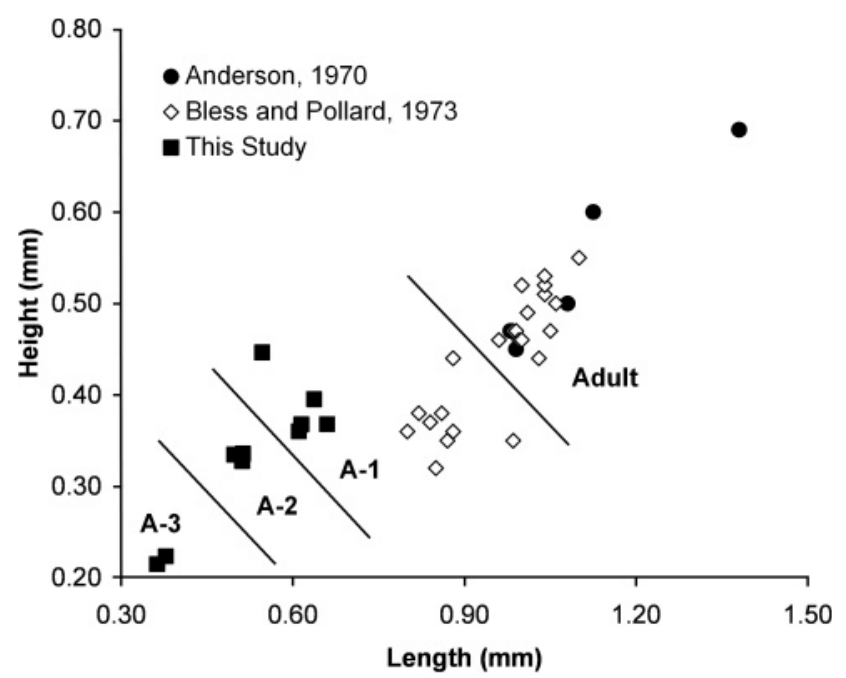

Fig. 3. Plot of length versus height of Carbonita evelinae specimens from Eskridge samples, Anderson (1970) and Bless \& Pollard (1973) showing groupings of adults and instars A-1 to A-3.

Graphs of ontogenetic series can show instar and adult stages where specimens are clustered. Stages can be difficult or impossible to distinguish, especially in the fossil record. This blurring of growth stages may result from time-averaging of specimens from different environments or seasons (Whatley \& Stephens, 1977). Conspecific ostracodes tend to be smaller in the spring than in the fall (Whatley \& Stephens, 1977). Brooks' rule suggests that crustaceans double their volume and increase linear dimensions by approximately the cube root of two (1.26) with each moult (Brooks, 1886). The rule is a general observation of crustacean growth but is not necessarily true of all ostracode ontogenies. Brooks' rule is useful for recognizing instars and adults of ostracodes and may provide insight into heterochrony in the evolution of the Ostracoda or into the timing of such ontogenetic changes as addition of appendages and development of sexual maturity.

Ten complete valves of $C$. evelinae were collected, representing three distinct instars (Fig. 3; Pl. 1, figs 1-3). Bless \& Pollard (1973) constructed a growth series of specimens of C. evelinae from the Westphalian of Great Britain and the Netherlands. Their data demonstrate two clusters of data points with mean height and length of approximately $0.37 \mathrm{~mm}$ and $0.87 \mathrm{~mm}$ and approximately $0.49 \mathrm{~mm}$ and $1.02 \mathrm{~mm}$, respectively. Bless \& Pollard (1973) inferred these two clusters to be the A-1 instar and the adult. If so, then the three instars in the Eskridge samples are probably the A-1 to A-3 instars, suggesting that no adults were collected. The largest specimens here have a mean height of $0.39 \mathrm{~mm}$, similar to that of Bless \& Pollard's A-1. While the mean height of instar A-1 of their specimens is similar to those in the Eskridge samples, the mean length differs: Eskridge specimens average $0.61 \mathrm{~mm}$ in length compared with $0.87 \mathrm{~mm}$ for Bless \& Pollard's (1973). Their specimens range in height: length ratio from 0.36 to 0.52 , while the Eskridge specimens range from 0.56 to 0.82 . Such differences could stem from the very small sample size of the current study, be the result of environmental differences or be due to taxonomic differences. Specifically, the $C$. evelinae here may be, instead, C. humilis Jones \& Kirkby, 1879, as this species has also a punctate surface

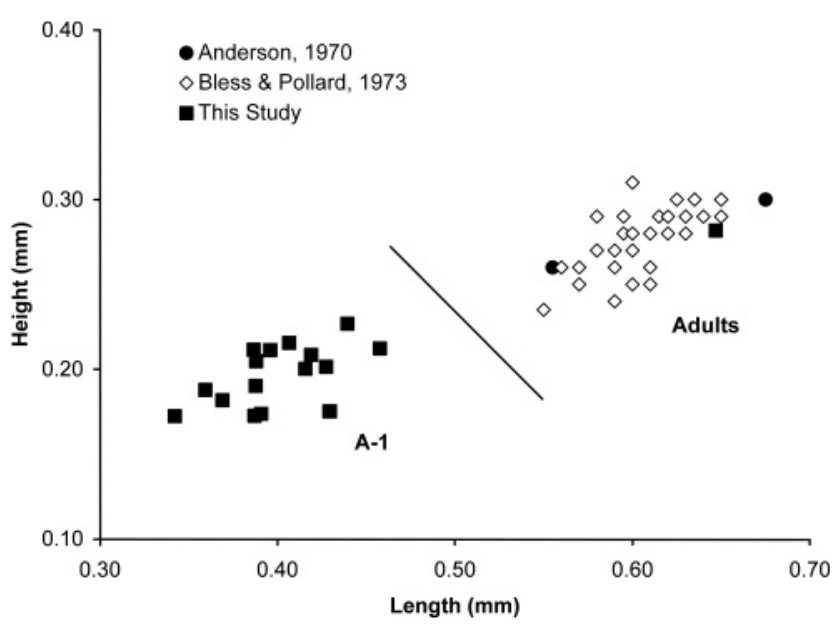

Fig. 4. Plot of length versus height of Carbonita pungens specimens from Eskridge samples, Anderson (1970) and Bless \& Pollard (1973) showing groupings of adults and instar A-1.

ornamentation and a height: length ratio of 0.60 to 0.70 (Pollard, 1966). C. humilis, however, has rounded, not elongated punctae as is characteristic of C. evelinae and its anterior end is pointed more acutely than that of C. evelinae. The dearth of specimens of $C$. evelinae in the current samples makes it difficult to determine whether these specimens of C. evelinae follow Brooks' rule (Fig. 3).

The specimens of $C$. pungens are a single valve of an adult and 17 A-1 instars (Fig. 4; Pl. 1, figs 4-6). The adult specimen is similar in size to Bless \& Pollard's (1973) adults, which have a mean height and length of $0.28 \mathrm{~mm}$ and $0.60 \mathrm{~mm}$, respectively (Fig. 4). Specimens measured and illustrated by Anderson (1970) are $0.30 \mathrm{~mm}$ by $0.68 \mathrm{~mm}$ and $0.26 \mathrm{~mm}$ by $0.56 \mathrm{~mm}$, both comparable in size to the adult specimen here (Fig. 4).

The samples yielded specimens of C. ovata $\mathrm{n}$. sp. from adults to the A-3 instar (Fig. 5a; Pl. 1, figs 7-8). Adults and A-3 instars are easily identifiable, with gaps separating them from other instars. Instars A-1 and A-2, however, have a broad distribution, with no appreciable gap between them. The dotted line in Figure 5a, separating the A-1 and A-2 instars, is based on Brooks' rule. This divided the collection into 16 adults, 38 A-1 instars, 39 A-2 instars and 8 A-3 instars. Adult height: length ratios range from 0.52 to 0.68 . The width of adult valves was also measured to show variation in the posterior end and to assess sexual dimorphism. Widths of adults seem to be distributed bimodally, with four adults having a width less than $0.18 \mathrm{~mm}$ and nine adults having a width greater (Fig. 6a), suggestive of sexual dimorphism, although further investigation with a larger sample size is needed.

The samples yielded 53 specimens of $C$. triangulata $\mathrm{n}$. sp.: 13 adults, 19 A-1 instars, 29 A-2 instars, and 2 A-3 instars (Fig. 5b; Pl. 1, figs 13-14). Adult and all instars are easily identifiable, with gaps separating them from one another. Adult height: length ratios range from 0.58 to 0.69 . The widths of adults may be distributed bimodally, with seven adults having a width less than $0.19 \mathrm{~mm}$ and six adults having a greater width (Fig. 6b), again suggestive of sexual dimorphism.

Variation in size and height: length ratios of adults of both $C$. ovata $\mathrm{n}$. sp. and C. triangulata $\mathrm{n}$. sp. could result from sexual 


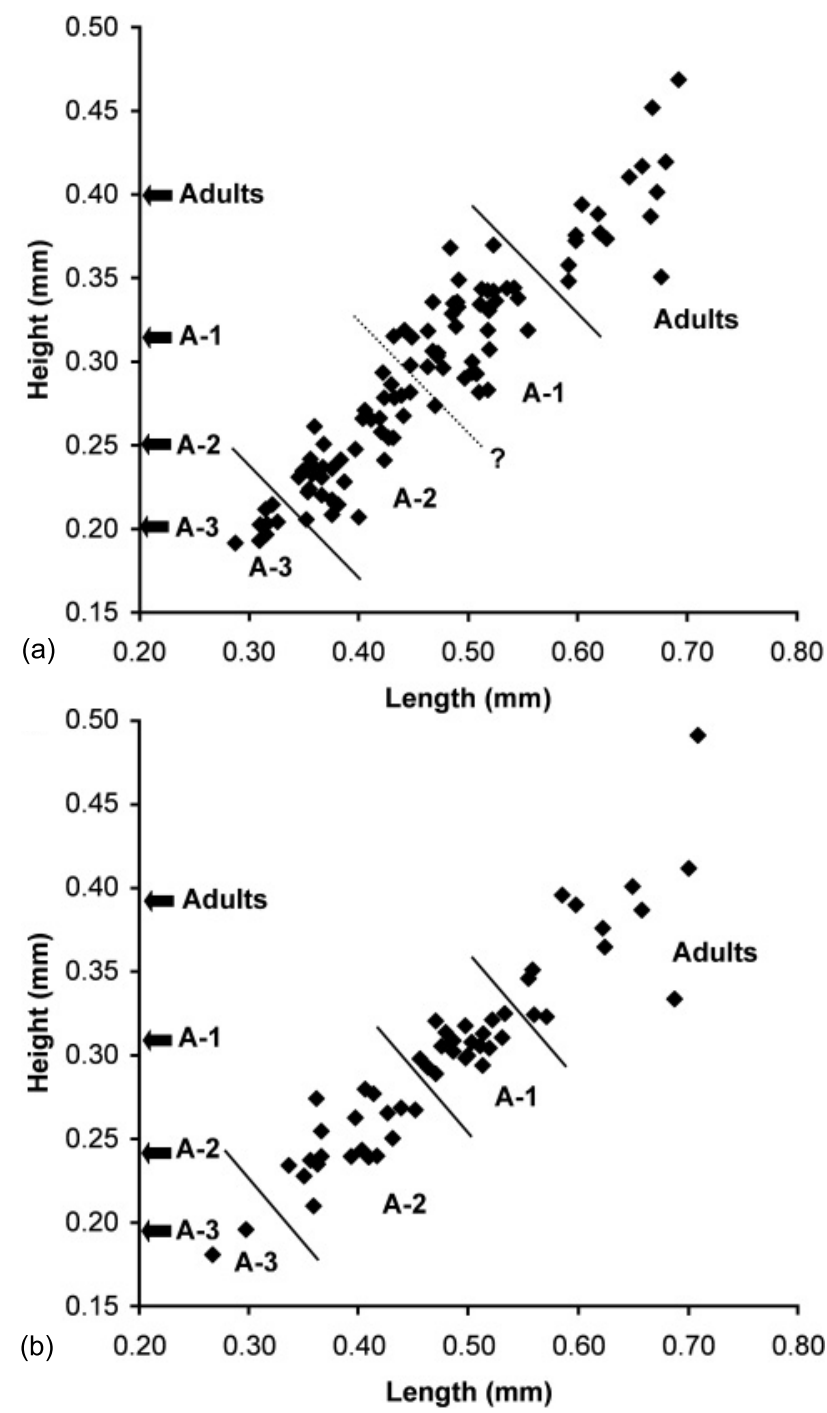

Fig. 5. Plot of length versus height of (a) Carbonita ovata n. sp. and (b) C. triangulata $\mathrm{n}$. sp. specimens from Eskridge samples, showing groupings of adults and instars A-3. Instar heights as predicted by Brooks' rule are marked on the ordinate with arrows, beginning with the mean height of instar A-3 stage, each subsequent arrow being located 1.26 times the previous height. The dotted line separating the A-1 and A-2 instars in (a) was calculated based on Brooks' rule.

dimorphism, which has been postulated for C. humilis (Jones \& Kirkby, 1879) (Pollard, 1966; Bless \& Pollard, 1973, 1975) and C. inflata (Jones \& Kirkby, 1879) (Anderson, 1970), based on differences in the swelling of the posterior end. Bless \& Pollard $(1973,1975)$ found also noticeable differences in height: length ratios, degree of arching of the dorsum and relative positions of maximum height of $C$. humilis among ostracodes from separate localities. Bless \& Pollard (1975) recognized that the variation among localities could result also from conditions other than sexual dimorphism: parthenogenetic reproduction in an unstable environment or a combination of syngamic reproduction during unstable environmental times and parthenogenetic reproduction during stable environmental times.

Height: length ratios of adults of both $C$. ovata n. sp. and $C$. triangulata $\mathrm{n}$. sp. are quite variable, but their distribution is not
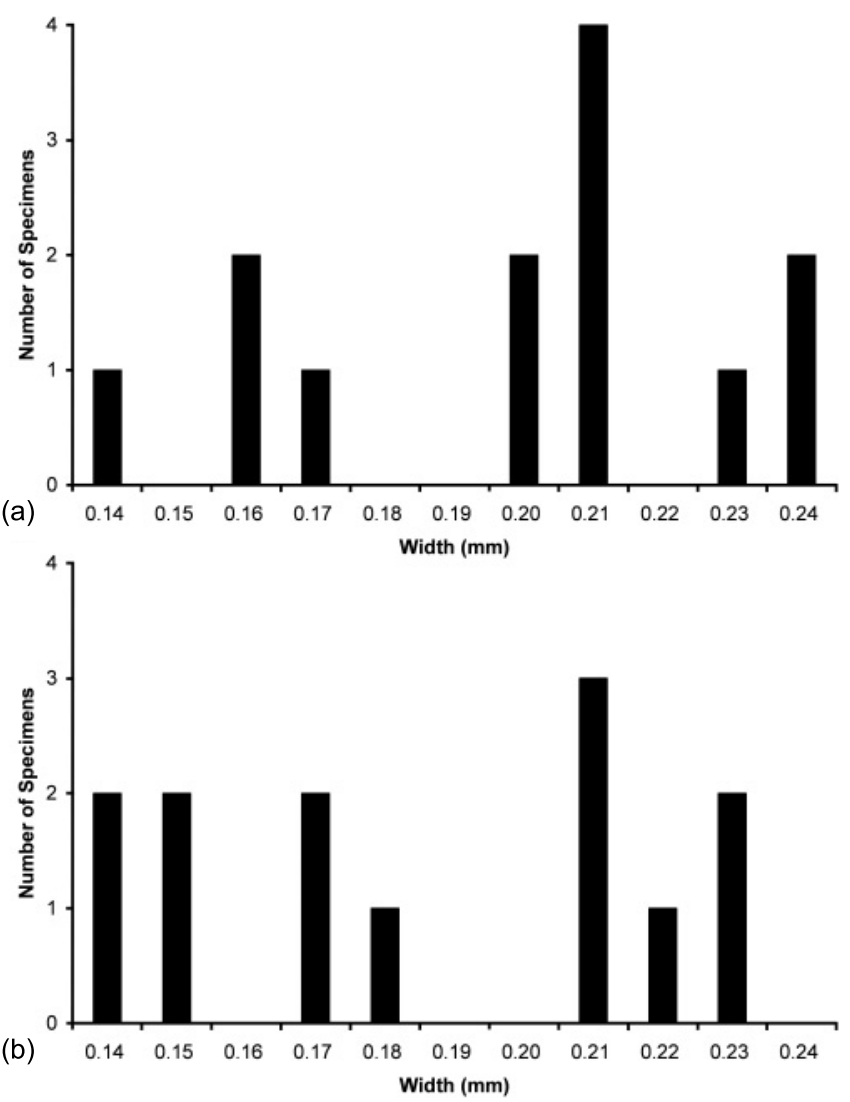

Fig. 6. Distribution of posterior widths of valves of adult specimens. The bimodal distribution suggests the two species are sexually dimorphic, presuming the males have the narrower posterior widths and the females are wider. (a) Carbonita ovata n. sp.; (b) C. triangulata n. sp.

bimodal and the amount of variation is similar to that of the A-1 and A-2 instars. The widths of the valves are distributed bimodally (Fig. 6). This may indicate that the variation in adult specimens is sexual dimorphism, or it may stem from life in an unstable environment and time-averaging of the fossils. It is unfeasible to speculate on sexual dimorphism and the nature of the variability in $C$. ovata $\mathrm{n}$. sp. and C. triangulata n. sp. until further information is available from study of larger collections that include other localities.

\section{EVOLUTIONARY AFFINITY}

Muscle-scar pattern, overlap of the hinges and free margins, ornamentation and shapes of species of Carbonita, along with their environment of deposition, have been used to establish their evolutionary affinities to other known ostracodes. Evolutionary affinities with the Superfamilies Cytheroidea (Knight, 1928), Cypridoidea (Scott \& Summerson, 1943; Swain, 1961, 1976) and Healdioidea (Sohn, 1985) have been suggested. Species of the Superfamily Darwinuloidea and the Late Palaeozoic genera Whipplella Holland, 1934, and Gutschickia Scott, 1944a, also have superficial similarities to some species of Carbonitidae (see Table 1). Although these taxa have not been suggested as ancestral to the carbonitids, Anderson (1970) and Bless \& Pollard (1973) suggested that the genera Whipplella and Gutschickia are synonymous with Carbonita. 


\begin{tabular}{llll}
\hline Superfamily & \multicolumn{1}{c}{ Range } & Overlap ventral margin & \multicolumn{1}{c}{ Muscle-scar pattern } \\
\hline Carbonitidae & Carboniferous-Permian & RV over LV & Circular outline with secondary scars \\
Cypridoidea & Triassic-Holocene & Both & Non-linear and non-radial pattern of secondary scars \\
Cytheroidea & Ordovician-Holocene & Both & Vertical rows of secondary scars \\
Darwinuloidea & Carboniferous-Holocene & RV over LV & Circular outline with elongated secondary scars \\
Healdioidea & Devonian-Cretaceous & LV over RV & Circular outline with secondary scars \\
Uncertain Superfamily Gutschickia & Carboniferous-Permian & RV over LV & Circular outline with secondary scars \\
Uncertain Superfamily Whipplella & Carboniferous-Permian & LV over RV & Circular outline with elongated secondary scars
\end{tabular}

Table 1. Summary of ranges and morphological characteristics of Carbonitidae, Cypridoidea, Cytheroidea, Darwinuloidea, Healdioidea, Gutschickia sp., Whipplella sp.

The value of muscle scars in the systematics of these Ostracoda has been debated. Scott (1944b) argued that muscle scars, when present, vary insignificantly within genera, whereas Gramm et al. (1972) found healdiid's muscle scars to be monotypic at the family level. Kristan-Tollmann (1977) judged that because fossil ostracodes have few characteristics, the musclescar pattern is of primary importance in taxonomic determination. Muscle-scar patterns of Bairdia McCoy, 1844, have changed little since the Carboniferous (Sylvester-Bradley, 1950). Alternatively, Smith (1964) found considerable variation in muscle scars among specimens of Cypridopsis vidua and Chlamydotheca arcuata Sars, 1901, and judged that they should not be used in classification.

Muscle scars of a few specimens of Carbonita pungens (Pl. 1, fig. 5) and C. triangulata n. sp. (Pl. 1, fig. 14) were observed and used to evaluate tentatively the evolutionary affinities. The muscle-scar pattern has an almost circular outline containing smaller secondary muscle scars within it (Figs 7a, c). Poor preservation of the muscle scar made it difficult to determine the number and shape of the secondary muscle scars, but they appear to be rounded to elongated (Figs 7b, d). Anderson's
(1970) illustration of the muscle-scar pattern of Carbonita shows peripheral scars surrounding a few central scars (Fig. 8a).

Sohn (1985) suggested that Carbonita's muscle-scar pattern resembles those of the Healdioidea. Pre-Carboniferous healdiid muscle-scar patterns are known only from a single Early Devonian species (Gramm, 1987). This species has a circular musclescar pattern with convex rows of 7-9 secondary muscle scars (Fig. 8b). Carboniferous and Permian healdiids have a circular muscle scar with many secondary muscle scars (Gramm et al., 1972; Kristan-Tollmann, 1977) (Fig. 8c). The secondary muscle scars can be divided into two groups: a central group of 6-8 secondary scars that vary in arrangement and a peripheral group that varies in arrangement and also in number (Gramm et al., 1972). The muscle scar of healdiids, as is true of Carbonita and many other kinds of ostracodes, is located slightly anterior of the median (Scott, 1944b).

The Superfamilies Cytheroidea and Cypridoidea both contain freshwater species and have been suggested as having evolutionary relationships to carbonitids (Knight, 1928; Scott \& Summerson, 1943; Swain, 1961, 1976). The muscle scars of both superfamilies differ from carbonitids in being not arranged

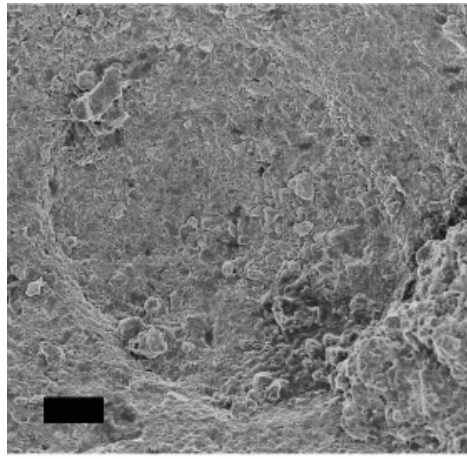

(a)

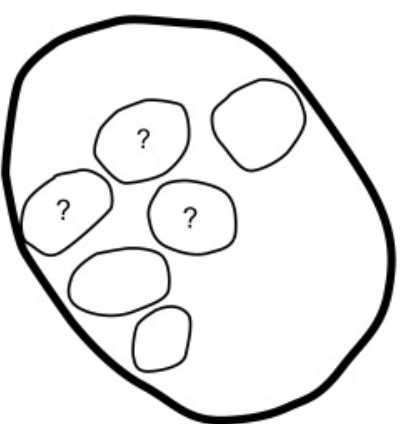

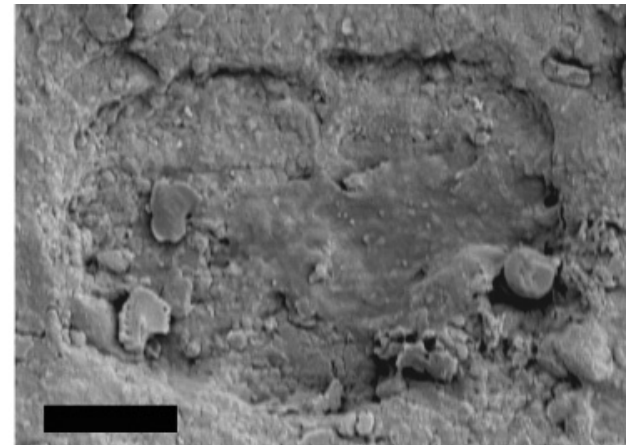

(c)

(d)

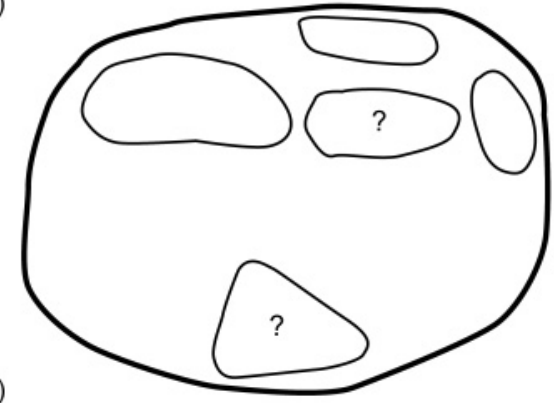

Fig. 7. Muscle-scar patterns and suggested secondary muscle scars. Scale bars represent $10 \mu \mathrm{m}$. (a, b) Carbonita triangulata n. sp.; (c, d) C. pungens. 


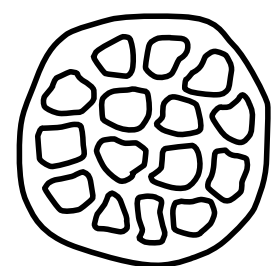

(a)

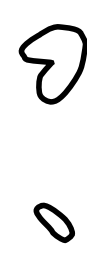

(e)

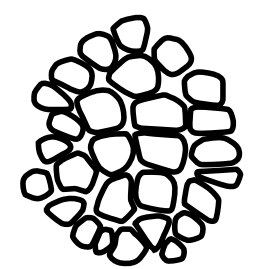

(b)

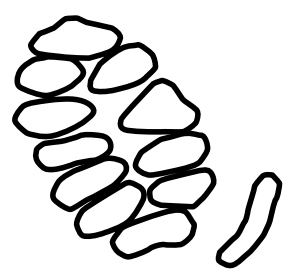

(f)

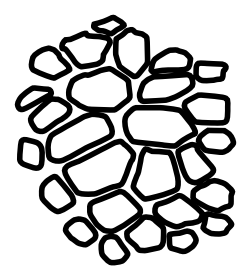

(c)

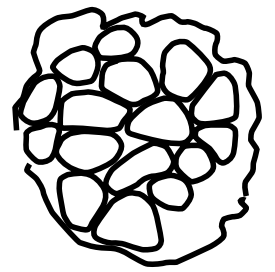

(g)

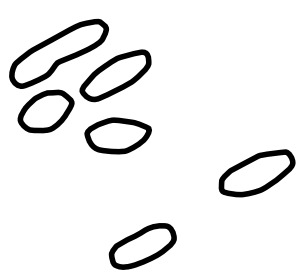

(d)

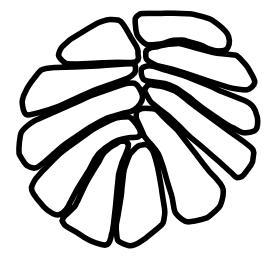

(h)

Fig. 8. Muscle-scar patterns of Carbonita and genera that have been considered to have evolutionary affinities with Carbonita. (a) Carbonita sp., redrawn from Anderson (1970, fig. 1g). (b) Healdia? obtusa (Abushik, 1971), Lower Devonian, redrawn from Gramm (1987, fig. 1). (c) Bythocyproidea sp., Mississippian, redrawn from Gramm et al. (1972, fig. 1). (d) Cypridopsis vidua (Müller, 1776), Holocene, redrawn from Moore (1961, fig. 21). (e) Cythere lutea (Brady \& Norman, 1889), Holocene, redrawn from Moore (1961, fig. 185). (f) Whipplella sp., Permian, redrawn from Sohn (1977, fig. 1). (g) Gutschickia sp., Pennsylvanian, redrawn from Sohn (1977, fig. 1). (h) Darwinula stevensoni (Brady \& Robertson, 1870), Holocene, redrawn from Sohn (1976, pl. 3).

circularly. Cyprid muscle-scar patterns contain a cluster of scars that is not radially or linearly arranged (Swain, 1961) (Fig. 8d), while cytherids have typically a nearly vertical row of four scars with a few anterior scars (Howe \& Sylvester-Bradley, 1961) (Fig. $8 \mathrm{e})$. Scars of both these superfamilies are less complex than the scars of healdiids and carbonitids.

Freshwater species of Carbonitidae, Whipplella, Gutschickia and Darwinuloidea all evolved during the Late Palaeozoic and have broadly similar muscle-scar patterns. The muscle-scar pattern of Whipplella comprises radially arranged, elongated secondary muscle scars (Fig. 8f) and resembles that of Suchonella Spizharsky, 1937 (Sohn, 1977). The muscle-scar pattern of Gutschickia is an almost circular outline containing smaller secondary muscle scars (Sohn, 1977) (Fig. 8g). The muscle-scar pattern of Darwinula Brady \& Robertson, 1885, consists of up to 12 palmate scars that are unequal in shape (Sohn, 1976) (Fig. 8h).

The muscle-scar pattern of carbonitids resembles closely those of Healdioidea and not those of Cytheroidea and Cypridoidea, thus suggesting that healdiids are closer evolutionary ancestors of carbonitids. The similarities in muscle-scar pattern of all the Late Palaeozoic freshwater genera, even those that have not been regarded as Carbonitidae, suggest also a close evolutionary affinity.

Another feature of Late Palaeozoic freshwater ostracodes to be used in classification is the valve overlap. Holland (1934) used valve overlap to distinguish species of Whipplella from Carbonita. Differences of valve overlap, however, may not be a good taxonomic indicator. Reversals are known to occur in Cytheroidea, Cypridoidea and Bairdioidea Sars, 1888, both among genera and within species (R. C. Whatley, pers. comm., 2004) and in Carbonita (Bless \& Pollard, 1973).

Valves of carbonitids have generally the right valve overlapping the left valve along the venter (Jones \& Kirkby, 1879; Anderson, 1970; Bless \& Pollard, 1973), with the exception of most specimens of $C$. pungens, which have the opposite pattern
(Bless \& Pollard, 1973). Darwinulids (Swain, 1961) and Gutschickia (Scott, 1944a) have the same overlap pattern as carbonitids, while in healdiids (Shaver, 1961) and Whipplella (Holland, 1934) the left valve overlaps the right. Cyprids and cytherids have both patterns of overlap. In the dorsum along the hinge, the left valve of Carbonita overlaps the right valve (Kellett, 1935; Anderson, 1970; Bless \& Pollard, 1973). The same pattern of dorsal overlap occurs in Gutschickia (Scott, 1944a), but Whipplella has the reverse overlap pattern, right valve over left valve (Holland, 1934).

Whether $C$. pungens belongs to the genus Carbonita or Darwinula has been debated. The general left over right valve overlap is the reverse of most Carbonita and Darwinula species, and it lacks also a dorsal overlap at the hinge, characteristic of Carbonita. The muscle-scar pattern of $C$. pungens has not been observed previously. Cooper (1946) reclassified $C$. pungens as Darwinula pungens after reviewing Pennsylvanian specimens from Illinois. His reclassification was based on the maximum valve overlap being around the ends, not around the ventral margin, and lack of a dorsal overlap at the hinge - both characteristics of carbonitids. His specimens' heights and lengths are larger than those of other $C$. pungens. Anderson (1970) retained C. pungens in the genus Carbonita but regarded Cooper's $D$. pungens to be not synonymous with C. pungens because the right valve overlapped the left valve along all free margins. Pollard (1966) and Bless \& Pollard (1973) disagreed with Anderson and regarded Cooper's specimens of D. pungens as Carbonita pungens, citing that the variance was the result of the structural simplicity of a small, thinly shelled species. Other Late Palaeozoic Darwinula species have been recognized from West Virginia (Sohn, 1976, 1985) and Virginia (Sohn, 1985) and have a typical darwinulid muscle-scar pattern. Some Darwinula species from Virginia are larger than $C$. pungens. Without being able to observe the muscle-scar pattern of $C$. pungens, its difference, if any, from Darwinula could not be assessed. 


\section{PALAEOENVIRONMENTAL INDICATIONS}

The presence of Carbonita species, charophytes [Stomochara moreyi (Peck, 1934)], lungfishes (Gnathorhiza sp.) and lysorophid amphibians (Brachydectes elongates Wellstead, 1991) and the absence of marine fossils in the green mudstone lens in the Speiser Shale indicate a freshwater environment, not a tidally influenced marine mudflat, as suggested previously (Schultze, 1985). Laterally adjacent to the mudstone lens is a red palaeosol (Hembree et al., 2004) that suggests it developed on a floodplain or coastal plain near a lake or pond (Picard \& High, 1972). The mudstone lens has been interpreted as a pond deposit that filled a topographic low, possibly the result of eolian deflation or a shallow temporary stream cut (Hembree et al., 2004). The pond's source of freshwater is likely to have been from rainwater or overland flow as a result of local flooding (Hembree et al., 2004).

The distribution of carbonitids is variable both laterally and vertically within the Eskridge pond. There is no evidence of pooling of specimens in the lysorophid burrows or of the accumulation of specimens at desiccation surfaces. The variable distribution is probably the result of abiotic factors of wind or water, predation, a combination of both, or poor preservation.

Many of the specimens are nested, with small instars inside larger instars or adults. Often only two specimens are nested, but in some instances three or four specimens are nested. Commonly the same species are nested with each other, but occasionally two species are nested together. Lane (1964) noticed similar nesting of carbonitid valves in other Lower Permian rock units in Kansas. The nesting could be the result of water or wind influences or such biotic factors as stacking within the digestive tract of a predator.

The Eskridge samples produced few adult specimens and no specimens of instars before A-3. This could be the result of poor preservation or of their being too rare to occur in the samples. The dearth of adult specimens could also be the result of an unstable environment. The small size and isolation of the pond would have made it sensitive to local fluctuations in seasonal climate (Picard \& High, 1972), producing an unstable environment for the carbonitids. Hembree et al. (2004) observed three subaerial exposure surfaces with desiccation features and lysorophid aestivation burrows within the pond lens, suggesting that these surfaces formed during drying episodes of the pond during dry seasons. Drying of the pond would have affected water quality and chemistry, including ionic strength, temperature, reduction-oxidation potential and $\mathrm{pH}$. Some modern freshwater ostracods species can be sensitive to temperature changes (Echols et al., 1975; Delorme, 1990, 1991) and specific conductivity and redox potential of the solution (J. L. Castle, pers. comm., 2004). A stressful and unstable environment may have caused the Eskridge carbonitids to have high juvenile mortality rates, dwarfism, or, less likely, early sexual maturity (Bless \& Pollard, 1975).

A few other assemblages of carbonitids have been described from the Cisuralian of Kansas (Lane, 1964; Peterson \& Kaesler, 1980). Lane (1964) found Carbonita associated commonly with darwinulids, fish teeth and scales, and Geisina Johnson, 1936, a brackish-water ostracode genus. They occurred also less commonly with Gutschickia and with charophytes. Lane (1964) interpreted the assemblages with darwinulids, charophytes and fish teeth and scales as occurring in freshwater deposits. The assemblages with Geisina were interpreted as being from freshwater to slightly brackish-water environments. He observed also that the assemblages of carbonitids were associated more commonly with green shales than red ones, suggesting that they were deposited in environments characterized by reduction of mud in a semi-permanent pond of freshwater or brackish water.

Peterson \& Kaesler (1980) collected an assemblage of six species of Carbonita from Upper Pennsylvanian deposits. They inferred the lagoon and tidal-mudflat sediments in which the assemblage was deposited to have been influenced strongly by influx of freshwater. One species, $C$. inflata, was abundant in the freshwater deposits but occurred commonly also in nearshore environments, indicating either tolerance of saline conditions and the ability to live in a variety of environments or that their carapaces were transported into these environments. Reexamination of specimens they identified as $C$. inflata show them to be conspecific with $C$. ovata n. sp.

\section{CONCLUSIONS}

The collection of four species of Carbonita from a Cisuralian pond deposit provides new and supporting information to the solution of problems associated with ontogeny, systematics, evolutionary affinities and palaeoenvironment indicators.

1. The assemblage of carbonitids, lungfish, lysorophids and charophytes in a mudstone lens indicates a freshwater pond environment, which agrees with the environmental interpretations of Hembree et al. (2004).

2. The dearth of adult specimens of Carbonita suggests a stressful and unstable environment. Stressful environmental conditions may have favoured either dwarfism or a high juvenile mortality rate.

3. The circular muscle-scar pattern of Carbonita with secondary muscle scars and its location anterior of the median suggest a close affinity to the healdiids, as Sohn (1985) proposed.

4. Differences in muscle-scar pattern and geological ranges indicate no close affinity to either cytherids or cyprids as proposed by Knight (1928) and Scott \& Summerson (1943), respectively.

5. The circular muscle-scar patterns of $C$. pungens are the first to be described for the species, but the arrangement of the secondary muscles could not be ascertained. The carapace of $C$. pungens is similar in shape to that of the darwinulids, but additional study of specimens with better-preserved muscle scars is essential to determining their affinity.

6. The posterior widths of adult specimens of $C$. ovata n. sp. and $C$. triangulata n. sp. indicate a bimodal distribution, suggestive of sexual dimorphism in these species.

\section{SYSTEMATIC PALAEONTOLOGY}

Repository. Types, figured specimens and other specimens studied are housed in the Division of Invertebrate Paleontology of the University of Kansas Natural History Museum and Biodiversity Research Center as specimens KUMIP 1,136,671 to $1,137,077$. Specimens with the prefix NHM are in the Natural History Museum, London. 


\author{
Phylum Arthropoda Siebold \& Stannius, 1845 \\ Class Crustacea Pennant, 1777 \\ Subclass Ostracoda Latreille, 1806 \\ Order Podocopida Müller, 1894 \\ Suborder Metacopina Sylvester-Bradley, 1961 \\ Superfamily Healdioidea Harlton, 1933 \\ Family Carbonitidae Swain, 1976 \\ Genus Carbonita Strand, 1928
}

Type species. Carbonia agnes Jones, 1870; designated subsequently by Bassler \& Kellett, 1934, p. 237.

Diagnosis. Anderson (1970, p. 74) emended the diagnosis of Carbonita as follows:

Subovate, ovate, or elongate-ovate carapace narrowest and lowest at anterior end. Right valve larger (vice versa in inverse forms) overlapping the left ventrally and to a less extent anteriorly and posteriorly. Both valves swollen dorsally and extending above the hinge-line; smaller valve extending higher than the larger. Hinge-line straight and occupying the middle third of valve. Adductor muscle attachment a number of small translucent areas situated in a circular pit. Carapace frequently showing a narrow, sinuous internal thickening running vertically across behind the pit, sometimes also in front. The outer surface of the carapace may be smooth, finely punctate, striated, or reticulate, but sometimes only the inner surface is punctate. Hinge consisting of a shallow groove in the smaller valve accommodating a simple adont ridge in the larger valve.

\section{Carbonita evelinae (Jones, 1870)}

(P1. 1, figs 1-3)

1870 Carbonia evelinae Jones: 220, pl. 9, fig. 4.

1870 Carbonia agnes rugulosa Jones: 220, pl. 9, fig. 8.

1870 Carbonia agnes subrugulosa Jones: 220, pl. 9, fig. 10.

1934 Carbonita evelinae (Jones); Bassler \& Kellett: 237.

1943 Hilboldtina evelinae (Jones); Scott \& Summerson: 670.

1943 Hilboldtina multiplicata Scott \& Summerson: 670, pl. 1, figs $22-25$.

1957 Hilboldtina evelinae (Jones); Copeland: 28, pl. 1, figs 5-7.

1966 Carbonita evelinae (Jones); Pollard: 686, fig. 7.

1970 Carbonita evelinae (Jones); Anderson: 78, pl. 7, figs 6-12.

1973 Carbonita evelinae (Jones); Bless \& Pollard: 32, fig. 6, pl. 1 , figs $1-9$.

Diagnosis. A species of Carbonita characterized by an ovate carapace covered externally with fine longitudinal striae formed by rows of closely set elongated punctae.

Lectotype. Adams Collections No. 8, NHM. In. 56370, specimen marked 9. Selected by Anderson (1966, p. 693).

Material. Ten unbroken valves including five A-1 instars, three A-2 instars and two A-3 instars from eight samples. KUMIP $1,136,686$ to $1,136,689$ and $1,136,694$ to $1,136,716$.

Locality. Road cut $2 \mathrm{~km}$ east of Eskridge, Kansas, from the Cisuralian Speiser Shale, samples from a green, carbonate-rich mudstone and claystone lens, approximately $10 \mathrm{~m}$ above the base.
Description. Carapace ovate to elongate. Dorsal margin slightly arched; ventral margin slightly concave to convex. Left valve slightly overlapping of right valve at hinge; right valve strongly overlapping left valve along free margin, especially ventrally. Anterior end rounded; posterior end pointed more acutely. Dorsal view ovate, greatest width medial to posterior. Anterior view rounded. Surface ornamentation elongated punctae.

Dimensions. A-1 instars, mean height $0.39 \mathrm{~mm}$, standard deviation $0.04 \mathrm{~mm}$; mean length $0.61 \mathrm{~mm}$, standard deviation $0.04 \mathrm{~mm}$. A-2 instars, mean height $0.33 \mathrm{~mm}$, standard deviation $0.00 \mathrm{~mm}$, mean length $0.51 \mathrm{~mm}$, standard deviation $0.01 \mathrm{~mm}$. A-3 instars, mean height $0.22 \mathrm{~mm}$, standard deviation $0.01 \mathrm{~mm}$; mean length $0.37 \mathrm{~mm}$, standard deviation $0.01 \mathrm{~mm}$.

Distribution. Cisuralian, Kansas; Upper Westphalian A, Netherlands (Bless \& Pollard, 1973); Westphalian C, Britain (Bless \& Pollard, 1973; Anderson, 1970); Westphalian D, Britain (Anderson, 1970); Westphalian A, Nova Scotia (Copeland, 1957); and Pennsylvanian of eastern USA (Scott \& Summerson, 1943).

Remarks. The largest specimens from the Speiser Shale are smaller than Bless \& Pollard's (1973) adults, perhaps for reasons discussed earlier.

\section{Carbonita pungens (Jones \& Kirkby, 1867)}

(Pl. 1, figs 4-6)

1867 Cythere pungens Jones \& Kirkby: 222.

1879 Carbonia pungens (Jones \& Kirkby): 37, pl. 3, figs 21-23.

1934 Carbonita pungens (Jones \& Kirkby); Bassler \& Kellet: 239.

1957 Carbonita pungens (Jones \& Kirkby); Copeland: 26.

1966 Carbonita pungens (Jones \& Kirkby); Pollard: 689.

1970 Carbonita pungens (Jones \& Kirkby); Anderson: 98, pl. 18, figs 81-86.

1973 Carbonita pungens (Jones \& Kirkby); Bless \& Pollard: 29, fig. 4.

Diagnosis. A species of Carbonita characterized by a small, smooth elongated carapace. Anterior margin acutely pointed. Dorsal margin arched to convex.

Lectotype. NHM I. 1731. T. R. Jones Coll. Selected by Anderson (1966, p. 694).

Material. 18 unbroken valves including 1 adult and 17 A-1 instars from 8 samples. KUMIP $1,136,690$ to $1,136,693$ and $1,136,717$ to $1,136,744$.

Locality. Same as for C. evelinae.

Description. Carapace elongate. Dorsal margin arched; ventral margin straight. Left valve slightly overlapping of right valve along free margin. Anterior end rounded to pointed; posterior end rounded. Dorsal view ovate, greatest width medial to posterior. Anterior view rounded. Surface ornamentation smooth. Muscle-scar pattern circular, arrangement of secondary muscle scars not ascertained. 
Dimensions. Adult, height $0.28 \mathrm{~mm}$; length $0.65 \mathrm{~mm}$. A-1 instars, mean height $0.20 \mathrm{~mm}$, standard deviation $0.02 \mathrm{~mm}$, mean length $0.40 \mathrm{~mm}$, standard deviation $0.03 \mathrm{~mm}$.

Distribution. Cisuralian, Kansas; Upper Westphalian A, Netherlands; Lower Westphalian C, Britain (Bless \& Pollard, 1973); Visean and Namurian of Scotland; Westphalian A-D, Britain (Pollard, 1966; Anderson, 1970); Limburg (Bless, 1967); Westphalian A and B, Nova Scotia (Copeland, 1957); and France (Pruvost, 1911).

Remarks. The left valve over right valve overlap is the reverse of typical Carbonita. The elongated carapace shape and valve overlap resemble closely those of the Permian Darwinula hollandi Scott, 1944a. Scott (1944a), however, found no muscle scars of $D$. hollandi.

\section{Carbonita ovata $\mathrm{n}$. sp.}

(Pl. 1, figs 7-12)

1980 Carbonita inflata (Jones \& Kirkby, 1879): Peterson \& Kaesler

Derivation of name. From the characteristic ovate shape in lateral view.

Diagnosis. A species of Carbonita characterized by a smooth ovate carapace.

Holotype. KUMIP 1,136,671.

Paratypes. KUMIP $1,136,672$ to $1,136,678$ and $1,136,745$ to $1,136,977$.

Material. 101 unbroken valves including 16 adults, 38 A-1 instars, 39 A-2 instars and 8 A-3 instar from 8 samples.

Locality. Same as for C. evelinae.

Description. Carapace ovate. Dorsal margin convex to slightly arched; ventral margin convex. Left valve slightly overlapping of right valve at hinge; right valve strongly overlapping left valve along free margin, especially ventrally. Anterior end rounded; posterior end more broadly rounded. Dorsal view ovate, greatest width posterior of median. Anterior view rounded. Relative shape of adults and A-1 similar. Possible sexual dimorphism in adults with presumed female having greater posterior width. Surface smooth.

Dimensions. Adults, mean height $0.39 \mathrm{~mm}$, standard deviation $0.03 \mathrm{~mm}$; mean length $0.64 \mathrm{~mm}$, standard deviation $0.04 \mathrm{~mm}$. A-1 instars, mean height $0.32 \mathrm{~mm}$, standard deviation $0.02 \mathrm{~mm}$; mean length $0.50 \mathrm{~mm}$, standard deviation $0.03 \mathrm{~mm}$. A-2 instars, mean height $0.25 \mathrm{~mm}$, standard deviation $0.02 \mathrm{~mm}$, mean length $0.39 \mathrm{~mm}$, standard deviation $0.03 \mathrm{~mm}$. A-3 instar, mean height $0.20 \mathrm{~mm}$, standard deviation $0.01 \mathrm{~mm}$; mean length $0.31 \mathrm{~mm}$, standard deviation $0.01 \mathrm{~mm}$.

Distribution. Upper Pennsylvanian to Cisuralian of Kansas.
Remarks. The carapace of C. ovata $\mathrm{n}$. sp. is shaped similarly to C. inflata (Jones \& Kirkby, 1879) but lacks the punctae ornamentation and the specimens from the current study are smaller. Widths of the posterior portions of adult specimens are distributed bimodally, suggesting sexual dimorphism. All specimens identified by Peterson \& Kaesler (1980), which were from Upper Pennsylvanian rocks of Kansas, belong to this new species.

\section{Carbonita triangulata $\mathrm{n}$. sp.}

(Pl. 1, figs 13-16)

Derivation of name. From the characteristic triangular shape.

Diagnosis. A species of Carbonita characterized by a smooth triangular carapace.

Holotype. KUMIP 1,136,680.

Paratypes. KUMIP $1,136,681$ to $1,136,685$ and $1,136,978$ to $1,137,077$.

Material. 53 unbroken valves including 13 adults, 19 A-1 instars, 19 A-2 instars, and 2 A-3 instar from 8 samples.

Locality. Same as for C. evelinae.

Description. Carapace triangular. Dorsal margin arched; ventral margin concave. Left valve slight overlap of right valve at hinge; right valve strongly overlapping left valve along free margin, especially ventrally. Anterior end rounded; posterior end more acutely pointed. Dorsal view ovate, greatest width median to posterior. Anterior view rounded. Relative shape of adults and A-1 similar. Possible sexual dimorphism in adults with presumed female having greater posterior width. Surface ornamentation smooth. Muscle-scar pattern circular, arrangement of secondary muscle scars not ascertained.

Dimensions. Adults, mean height $0.38 \mathrm{~mm}$, standard deviation $0.05 \mathrm{~mm}$; mean length $0.62 \mathrm{~mm}$, standard deviation $0.06 \mathrm{~mm}$. A-1 instars, mean height $0.31 \mathrm{~mm}$, standard deviation $0.01 \mathrm{~mm}$; mean length $0.50 \mathrm{~mm}$, standard deviation $0.02 \mathrm{~mm}$. A-2 instars, mean height $0.25 \mathrm{~mm}$, standard deviation $0.02 \mathrm{~mm}$, mean length $0.39 \mathrm{~mm}$, standard deviation $0.03 \mathrm{~mm}$. A-3 instar, mean height $0.19 \mathrm{~mm}$, standard deviation $0.01 \mathrm{~mm}$; mean length $0.28 \mathrm{~mm}$, standard deviation $0.02 \mathrm{~mm}$.

\section{Distribution. Cisuralian of Kansas.}

Remarks. The carapace is shaped similarly to C. subangulata (Jones \& Kirkby, 1879). C. subangulata, however, is known only from Mississippian rocks and the specimens from the current study are appreciably smaller than C. subangulata described in the literature (Anderson, 1970), suggesting that the two are not conspecific. Widths of the posterior portions of adult specimens are distributed bimodally, indicating sexual dimorphism 


\section{ACKNOWLEDGEMENTS}

The authors are grateful to S. T. Hasiotis, J. A. Roberts, R. F. Lundin, N.E. Tibert, S. Crasquin-Solvie and an anonymous reviewer for their suggestions for improving an earlier version of the manuscript and to D. I. Hembree for assistance in the field. The University of Kansas Department of Geology provided financial support.

\section{Manuscript received 21 September 2004 Manuscript accepted 23 April 2005}

\section{REFERENCES}

Abushik, A.F. 1971. Ostracodes from the reference section through the Silurian and Lower Devonian in Podolia. Paleozoysiye ostrakody iz opornykn razrezov yevropeyskoy chasti SSSR. Nauka Press, Moscow, $7-133$.

Anderson, F.W. 1966. In: Pollard, J. E. Postscript. Palaeontology, 9: 693-694.

Anderson, F.W. 1970. Carboniferous Ostracoda - the genus Carbonita Strand. Great Britain Geological Survey Bulletin, 32: 69-121.

Baird, W. 1845. Arrangement of the British Entomostraca, with a list of species, particularly noticing those which have as yet been discovered within the bounds of the club. Berwickshire Naturalists Club [History] Proceedings [1842-1849]: 145-158.

Baird, W. 1850. The natural history of the British Entomostraca. The Ray Society, London, 364pp.

Bassler, R.S. \& Kellet, B. 1934. Bibliographic index of Paleozoic Ostracoda. Geological Society of America Special Papers, 1: 1-500.

Bless, M.J.M. 1967. Ostracoden aus dem Limburg Karbon (Niederlande). Freiberger Forschungshefte, C213: 159-169.

Bless, M.J.M. \& Pollard, J.E. 1973. Paleoecology and ostracode faunas of Westphalian ostracode bands from Limburg, The Netherlands and Lancashire, Great Britain. Mededelingen Rijks Geologische Dienst, Nieuwe Serie, 24: 21-53.

Bless, M.J.M. \& Pollard, J.E. 1975. Quantitative analysis of dimorphism in Carbonita humilis (Jones and Kirkby). In: Swain, F.M., Kornicker, L.S. \& Lundin, R.F. (Eds), Biology and Paleobiology of Ostracoda. Paleontological Research Institution, Ithaca, NY, 109-127.

Brady, G.S. 1867. Report on the Ostracoda dredged amongst the Hebrides. British Association for the Advancement of Science Report for 1866: 208-211.

Brady, G.S. \& Norman, A.M. 1889. A monograph of the marine and freshwater Ostracoda of the North Atlantic of northwestern Europe. Section I. Podocopa. Royal Dublin Society, Scientific Transactions, series 2, 4: 63-270.

Brady, G.S. \& Robertson, D. 1870. The Ostracoda and Foraminifera of tidal rivers. The Annals and Magazine of Natural History, 6: 1-33.

Brady, G.S. \& Robertson, D. 1885. Genus Darwinula. In: Jones, T. R., On the Ostracoda of the Purbeck formation; with notes on the Wealden species. Geological Society of London Quarterly Journal, 41(3): 346.

Brooks, W.K. 1886. Report on the scientific results of the voyage of H.M.S. Challenger. Zoology, 16(45).

Cooper, C.L. 1942. Occurrence and stratigraphic distribution of Paleozoic ostracodes. Journal of Paleontology, 16: 764-776.

Cooper, C.L. 1946. Pennsylvanian ostracodes of Illinois. Bulletin of the Geological Survey of Illinois, 70: 1-177.

Copeland, M.J. 1957. The arthropod fauna of the Upper Carboniferous rocks of the Maritime Provinces. Memoirs of the Geological Survey of Canada, 286: 1-72.

Delorme, L.D. 1990. Methods in Quaternary ecology \#7. Freshwater ostracodes, Geoscience Canada, 16: 85-90.

Delorme, L.D. 1991. Ostracoda. In: Thorp, J.H. \& Covich, A.P. (Eds), Classification of North American Freshwater Invertebrates. Academic Press, Inc., New York, 691-721.

Dickinson, W.R., Soreghan, G.S. \& Giles, K.A. 1994. Glacio-eustatic origin of Permo-Carboniferous stratigraphic cycles: Evidence from the southern Cordilleran foreland region. In: Dennison, J.M. \& Ettensohn, F.R. (Eds), Tectonic and Eustatic Controls on Sedimentary
Cycles. Society of Economic Paleontologists and Mineralogists, Concepts in Sedimentology and Paleontology, 4: 25-34.

Echols, D.J., Price, L.G. \& Raffle, M.A. 1975. Variations in fresh-water ostracode populations from lakes in St. Louis County, Missouri. In: Swain, F. (Ed.), Biology and Paleobiology of Ostracoda. Bulletins of American Paleontology, 65: 167-172.

Frazier, W.J. \& Schwimmer, D.R. 1987. Regional Stratigraphy of North America. Plenum Press, New York and London, 303-309.

Gramm, M.N. 1987. The central muscle area of some Paleozoic ostracodes. Paleontological Journal, 21: 61-71.

Gramm, M.N., Gurevich, K.Y., Kotschetkova, N.M. \& Smirnova, R.F. 1972. Adductor scars of Paleozoic Healdiidae (Ostracoda). Paleontological Journal, 6: 117-121.

Harlton, B.H. 1933. Micropaleontology of the Pennsylvanian Johns Valley Shale of the Ouachita Mountains, Oklahoma, and its relationship to the Mississippian Caney Shale. Journal of Paleontology, 7: 3-29.

Hattin, D.E. 1957. Depositional environment of the Wreford Megacyclothem (Lower Permian) of Kansas. Kansas Geological Survey Bulletin, 124: 1-117.

Hembree, D.I., Martin, L.D. \& Hasiotis, S.T. 2004. Amphibian burrows and ephemeral pond of the Lower Speiser Shale, Kansas: Evidence for seasonality in the Midcontinent. Paleogeography, Paleoclimatology, Paleoecology, 203: 127-152.

Holland, W.C. 1934. The ostracods of the Nineveh Limestone of Pennsylvania and West Virginia. Annals of the Carnegie Museum, 22: 343-351.

Howe, H.V. \& Sylvester-Bradley, P.C. 1961. In: Moore, R.C. (Ed.), Treatise on Invertebrate Paleontology, Part Q, Arthropod 3. University of Kansas Press and the Geological Society of America, Kansas and Boulder, Colorado, 254pp.

Johnson, W.R. 1936. Ostracoda of the Missouri Series in Nebraska. Nebraska Geological Survey Papers, 11: 1-52.

Jones, T.R. 1870. On some bivalved Entomostraca from the coalmeasures of south Wales. Geological Magazine, 7: 214-220.

Jones, T.R. \& Kirkby, J.W. 1867. On the Entomostraca of the Carboniferous rocks of Scotland. Transactions of the Geological Society of Glasgow, 2: 213-228.

Jones, T.R. \& Kirkby, J.W. 1879. Notes on the Paleozoic bivalved Entomostraca, No. 12. The Annals and Magazine of Natural History, 4: $28-40$.

Kellett, B. 1935. Ostracodes of the Upper Pennsylvanian and the lower Permian strata of Kansas: III. Bairdiidae (concluded), Cytherellidae, Cypridinidae, Entomoconchidae, Cytheridae and Cypridae. Journal of Paleontology, 9: 132-166.

Kellett, B. 1943. Permian ostracodes. Journal of Paleontology, 17: 615-628.

Knight, J.B. 1928. Some Pennsylvanian ostracodes from the Henrietta Formation of eastern Missouri. Journal of Paleontology, 2: 318-337.

Kristan-Tollmann, E. 1977. On the development of the muscle-scar patterns in Triassic Ostracoda. Proceeding of the International Symposium on Ostracods, 6: 133-143.

Lane, N.G. 1964. Paleoecology of the Council Grove Group (Lower Permian) in Kansas, based upon microfossil assemblages. Kansas Geological Survey Bulletin, 170 (5): 1-23.

Latreille, P.A. 1806. Genera crustaceorum et insectorum, Tomus I, 1806, p. I-XVIII. Parisiis et Argentorati, Paris, 303pp.

M'Coy, F. 1844. A synopsis of the characters of the Carboniferous Limestone fossils of Ireland. Dublin University Press, Dublin, 207pp.

Moore, M.C. (Ed.) 1961. Treatise on Invertebrate Paleontology, Part Q, Arthropod 3. University of Kansas Press and the Geological Society of America, Kansas and Boulder, Colorado, 1-442.

Müller, G.W. 1894. Die Ostracoden des Golfes von Neapel und der angrenzenden Meeres-abschnitte. Fauna und Flora Neapel, Monographie, 21: 1-404.

Müller, O.F. 1776. Zoologiae Danicae Prodromus, seu animalium Daniae et Norvegiae indigenarum characters, nomina, et synonyma imprimis popularium. Havniae, 8: 1-282.

Olszewski, T.D. \& Patzkowsky, M.E. 2003. From cyclothems to sequences: The record of eustasy and climate on an icehouse epeiric platform (Pennsylvanian-Permian, North American Midcontinent). Journal of Sedimentary Research, 73: 15-30. 
Peck, R.E. 1934. Late Paleozoic and early Mesozoic Charophyta. American Journal of Science, 27: 49-55.

Pennant, T. 1777. British Zoology. Volume IV. Crustacea, Mollusca, Testacea. B. White, London.

Peterson, R.M. \& Kaesler, R.L. 1980. Distribution and diversity of ostracodes assemblages from the Hamlin Shale and the Americus Limestone (Permian, Wolfcampian) in northeastern Kansas. University of Kansas Paleontological Contributions, 100: 1-26.

Picard, M.D. \& High, L.R. Jr 1972. Criteria for recognizing lacustrine rocks. In: Rigby, J.K. \& Hamblin, W.K. (Eds), Recognition of Ancient Sedimentary Environments. Society of Economic Paleontologists and Mineralogists Special Publication, 16: 108-145.

Pollard, J.E. 1966. A non-marine ostracod fauna from the coal measures of Durham and Northumberland. Palaeontology, 9: 667-697.

Pruvost, P. 1911. Note sur les Entomostraces bivalves du terrain houiller du nord de la France. Annales de la Société géologique du Nord, 40: $60-80$.

Rankey, E.C. 1997. Relations between relative changes in sea level and climate shifts: Pennsylvanian-Permian mixed carbonate-siliciclastic strata, western United States. Geological Society of America Bulletin, 109: $1089-1100$

Sars, G.O. 1888. Nye bidrag til kundskaben om Middlehavets invertebratfana, 4. Ostracoda Mediterranea. Archiv for Mathematik og Naturvidenskab, Oslo, 12: 173-324.

Sars, G.O. 1901. Contributions to the knowledge of the fresh-water Entomostraca of South America, as shown by artificial hatching from dried material. Archiv for Mathematik og Naturvidenskab, Oslo, 24 (1): $1-52$.

Schultze, H.S. 1985. Marine to onshore vertebrates in the lower Permian of Kansas and their paleoenvironmental implications. University of Kansas Paleontological Contributions, 113: 1-18.

Scott, H.W. 1944a. Permian and Pennsylvanian fresh-water ostracodes. Journal of Paleontology, 18: 141-147.

Scott, H.W. 1944b. Muscle scar patterns on some upper Paleozoic ostracodes. Journal of Paleontology, 18: 162-171.

Scott, H.W. \& Summerson, C.H. 1943. Non-marine Ostracoda from the Lower Pennsylvanian in the southern Appalachians, and their bearing on inter-continental correlation. American Journal of Science, 241: 653-675.

Shaver, R.H. 1961. In: Moore, R.C. (Ed.), Treatise on Invertebrate Paleontology, Part Q, Arthropod 3. University of Kansas Press and the Geological Society of America, Kansas and Boulder, Colorado, $1-442$.

Siebold, C.T.E. von \& Stannius, H. von (Eds) 1845. Lehrbuch ver Vergleichenden Anatomie.

Smith, R.N. 1964. Musculature and muscle scars of Chlamydotheca arcuata (Sars) and Cypridopsis vidua (O.F. Müller) (Ostracoda-Cyprididae). Doctoral Dissertation. University of Michigan, Ann Arbor, MI, 1-113.
Sohn, I.G. 1976. Antiquity of the adductor muscle attachment scar in Darwinula Brady \& Robertson, 1885. Abhandlungen und Verhandlungen Naturwissenschaftliches Vereins, Hamburg (NF), 18/19 ((Suppl.)): 305-308.

Sohn, I.G. 1977. Muscle scars of late Paleozoic freshwater ostracodes from West Virginia. Journal of Research of the U. S. Geological Survey, 5: 135-141.

Sohn, I.G. 1985. Latest Mississippian (Namurian A) nonmarine ostracodes from West Virginia and Virginia. Journal of Paleontology, 59: 446-460.

Spizharsky, T.N. 1937. Ostracoda from the Kolchugino Series of the coalbearing strata of the Kuznetsk basin. Central Geological and Prospecting Institute, Leningrad-Moscow, 97: 139-171.

Strand, E. 1928. Miscellanea nomenclatorica zoologica et palaeontologica. Archiv für Naturesgeschellschaft, 92: 40-41.

Swain, F.M. 1961. In: Moore, R.C. (Ed.), Treatise on Invertebrate Paleontology, Part Q, Arthropod 3. University of Kansas Press and the Geological Society of America, Kansas and Boulder, Colorado, 208-253.

Swain, F.M. 1976. Evolutionary development of cypridopsid Ostracoda. Abhandlungen und Verhandlungen Naturwissenschaftliches Vereins, Hamburg (NF), 18/19 (Suppl.): 103-118.

Sylvester-Bradley, P.C. 1950. The shell of the ostracod genus Bairdia. The Annals and Magazine of Natural History, 3: 751-756.

Sylvester-Bradley, P.C. 1961. In: Moore, R.C. (Ed.), Treatise on Invertebrate Paleontology, Part Q, Arthropod 3. University of Kansas Press and the Geological Society of America, Kansas and Boulder, Colorado, 1-442.

Tibert, N.E. \& Scott, D.B. 1999. Ostracodes and agglutinated foraminifera as indicators of paleoenvironmental change in an early Carboniferous brackish bay, Atlantic Canada. Palaios, 14: 246-260.

Watabe, K. \& Kaesler, R.L. 2004. Ontogeny of a new species of Paraparchites (Ostracoda) from the lower Permian Speiser Shale in Kansas. Journal of Paleontology, 78: 603-611.

Wellstead, C.F. 1991. Taxonomic revision of the Lysorophia, PermoCarboniferous lepospondyl amphibians. Bulletin of the American Museum of Natural History, 209: 1-90.

Whatley, R.C. \& Stephens, J.M. 1977. Precocious sexual dimorphism in fossil and recent Ostracoda. In: Löffler, H. \& Danielopol, D. (Eds), Aspects of Ecology and Zoogeography of Recent and Fossil Ostracoda. Dr. W. Junk b.v. Publishers, The Hague, 69-91.

Whatley, R.C., Siveter, D.J. \& Boomer, I.D. 1993. Arthropoda (Crustacea: Ostracoda). In: Benton, M.J. (Ed.), The Fossil Record 2. Chapman \& Hall, London, 343-356.

Zeller, D.E. (Ed.) 1968. The stratigraphic succession in Kansas. Kansas Geological Survey Bulletin, 189: 1-81. 